\title{
Phlebotominae (Diptera: Psycodidae) fauna in the Chaco region and Cutaneous Leishmaniasis transmission patterns in Argentina
}

\author{
Oscar D Salomón/ ${ }^{+}$, Juan R Rosa ${ }^{1}$, Marina Stein', María G Quintana², María S Fernández, \\ Andrés M Visintin ${ }^{3}$, Gustavo R Spinelli ${ }^{4}$, María M Bogado de Pascual ${ }^{5}$, María L Molinari ${ }^{5}$, \\ María L Morán ${ }^{6}$, Daniel Valdez ${ }^{6}$, Mario Romero Bruno
}

\begin{abstract}
Centro Nacional de Diagnóstico e Investigación en Endemo-epidemias, Av. Paseo Colón 568, 1063 Buenos Aires, Argentina ${ }^{1}$ Universidad Nacional del Nordeste, Chaco, Argentina ${ }^{2}$ Universidad Nacional de Tucumán, Tucumán, Argentina ${ }^{3}$ Universidad Nacional de Córdoba, Córdoba, Argentina ${ }^{4}$ Universidad Nacional de La Plata, LaPlata, Argentina ${ }^{5}$ Ministerio de Salud Pública Chaco, Chaco, Argentina ${ }^{6}$ Ministerio de Salud y Desarrollo Humano Santiago del Estero, Santiago del Estero, Argentina ${ }^{7}$ Ministerio de Desarrollo Humano Formosa, Formosa, Argentina
\end{abstract}

In Argentina, the incidence of American Cutaneous Leishmaniasis (ACL) has shown a steady increase over the last few decades. In the Chaco biogeographical region, specifically, several outbreaks of ACL were recently reported in addition to the usual time-space scattering of ACL cases. However, little is known about the sandfly composition in the eastern, humid Chaco (HC) region or the western, dry Chaco (DC) region. Therefore, phlebotomine captures were performed throughout this region and an analysis of the distribution of reported ACL cases was conducted in order to assess the vector diversity in ACL endemic and epidemic scenarios in the Chaco region. The results support the hypothesis of two distinct patterns: (1) the DC, where Lutzomyia migonei was the most prevalent species, had isolated ACL cases and a zoonotic cycle; (2) the HC, where Lutzomyia neivai was the most prevalent species, had an increase in ACL incidence and outbreaks and an anthropozoonotic cycle. The epidemic risk in the Chaco region may be associated with the current climate trends, landscape modification, connection with other ACL foci, and Lu. neivai predominance and abundance. Therefore, changes in sandfly population diversity and density in the Chaco region are an indicator of emergent epidemic risk in sentinel capture sites.

Key words: American Cutaneous Leishmaniasis - Chaco - Argentina - Lutzomyia migonei - Lutzomyia neivai

During the past few decades, Cutaneous Leishmaniasis incidence has increased globally at an alarming rate as a result of concomitant changes in micro-climate, land-use, migration and urbanization patterns, as well as other factors (Mott et al. 1990, Desjeux 2001, CampbellLendrum et al. 2001, Shaw 2007). Simultaneously, the "Gran Chaco" region has been attracting the attention of multilateral research efforts and funding agencies focused on health and environmental conservation, including organizations such as the Pan-American Health Organization/World Health Organization, Canada's International Development Research Center and the World Wildlife Fund (World Wide Fund for Nature).

The "Gran Chaco" region is a biogeographical area with threatened endemic flora and fauna that extends over more than $1,000,000 \mathrm{~km}^{2}$ of Paraguay, Bolivia and

Financial support: PAHO, Small Grants Program for Operational Research on Tropical Diseases, National Agency for Promotion of Science and Technology (ANPCyT - BID 1201/OC-AR-PICT R n 275), Fundacion Roemmers, and CyT; UNNE-ODS is member of the CONICET, Argentina.

+ Corresponding author: odanielsalomon@gmail.com

Received 2 June 2008

Accepted 8 September 2008 northeastern Argentina (Morello \& Adamoli 1968, Cabrera 1976, Zuleta \& Bolkovic 1994, Trucco Aleman 2007). In Argentina, above the $31^{\circ} \mathrm{S}$, the dry Chaco (DC) gently slopes from the Andean foothills eastwards towards the humid Chaco (HC), which is delimited on the east by the Parana River.

An increase in rain precipitation (Minetti \& Vargas 1997, Villalba et al. 1998) during the XX century has led to severe fragmentation of the Argentinean Chaco landscape due to the overgrazing of cattle, overexploitation of timber stocks, agricultural burns and, recently, the planting of transgenic soybean cultures (Adamoli et al. 1990, Bucher \& Huszar 1999). These environmental changes have been accompanied by intense migrationurbanization, as well as population impoverishment. More than 30\% (31.6\%) of the Argentinian Chacos' homes lack basic necessities (INDEC 2001).

American Cutaneous Leishmaniasis (ACL) cases in the Chaco region were found to be scattered both temporally and geographically. Outbreaks were reported that related to the deforestation of "hot spots" from the 1934 "Chaco war" (González \& Oliveira y Silva 1939, González \& Arce Queirolo 1955, Miranda et al. 1999). During the last 15 years, reports of ACL incidence and periurban outbreaks have increased (Salomón et al. 2001, Yadón et al. 2001, 2003). The endemic dispersion or epidemic concentration of different ACL transmission patterns was hypothesized to be associated with different phlebotominae diversity/abundance in the different landscapes (Salomon et al. 2006b, c). 
However, little is currently known about the sandfly fauna during the Chaco's epidemic and inter-epidemic periods. In this paper, we present unpublished findings from sandfly captures performed at different sites within the Argentinean Chaco since 2000. The captures were related to ACL human incidence and have been compared to the phlebotomine diversity/abundance of known epidemic scenarios. The results of these findings allow for the assessment of current and potential epidemic scenarios of ACL in the Chaco region. This paper, therefore, will facilitate the proper allocation of surveillance resources and contribute to future discussions about ACL emergence and environmental and climate changes.

\section{MATERIALS AND METHODS}

Area description - The Argentinean Chaco is divided by the isohyetal line of $900 \mathrm{~mm}$ into the $\mathrm{DC}$ and the HC. The $\mathrm{HC}$ is an eastern corridor with a maximum width of $200 \mathrm{~km}$, between $58^{\circ}-60^{\circ} \mathrm{W}$ (Fig. 1). In the western DC, the rainfall averages between 500 $800 \mathrm{~mm} /$ year (commensurate with the continental dry pattern), while in the $\mathrm{HC}$, the rainfall reaches 1,200 $\mathrm{mm}$ /year (commensurate with the Atlantic Humid pattern). The climate is subtropical, with a dry season that begins in June, persists through September and peaks in July. The rainy season begins in November, persists through March and peaks in spring and fall, with intensive short storms (UNNE 1987). The average annual temperature ranges from $28^{\circ} \mathrm{C}-14^{\circ} \mathrm{C}$, with a broad day/night amplitude (i.e., the temperature can rise $15^{\circ} \mathrm{C}$ in a couple of hours) and summer/winter amplitude $\left(0^{\circ} \mathrm{C}-45^{\circ} \mathrm{C}\right)$. The DC contains the "Heath Pole" of South America (Prohaska 1959) and a xeric landscape. On the other hand, the HC's main rivers (Parana and Paraguay) are lined by gallery forests alternating with grassed and flooded wetlands. The landscape is a mosaic that moves from the eastern savannas and grasslands to the western thorn forests and the open woodlands populated by Quebracho/Algarrobo and Quebracho/Palo Santo trees (Aspidosperma, Bulnesia, Schinopsis, Prosopis) and thorny shrubs and cacti (Morello \& Adamoli 1968, Cabrera 1976). This region boasts many endemic animals including the Chacoan Pecary (Catagonus wagneri) and it claims the highest known diversity of Armadillos ( $\mathrm{Zu}-$ leta \& Bolkovic 1994).

Phlebotomine captures - Adult phlebotomine sandflies were captured using CDC minilight traps (Sudia \& Chamberlain 1962) operated from 19h-9h over two nights at each site in the provinces of Santiago del Estero, Salta, Formosa and Chaco (coordinates, localities and dates are detailed in Table I and sites are reported in Fig. 1). Adult phlebotomine sandflies were also captured during November 2007 using a Malaise trap from 9h-21h after dusk, once in Córdoba, $10 \mathrm{~km}$ south to Icho Cruz, in Las Jarillas, a leisure point on the river shore

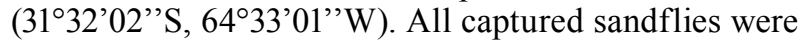
dry-stored until they were identified according to the characteristics published by Young and Duncan (1994) and Andrade Filho et al. (2003). In Monte Alto, Chaco,

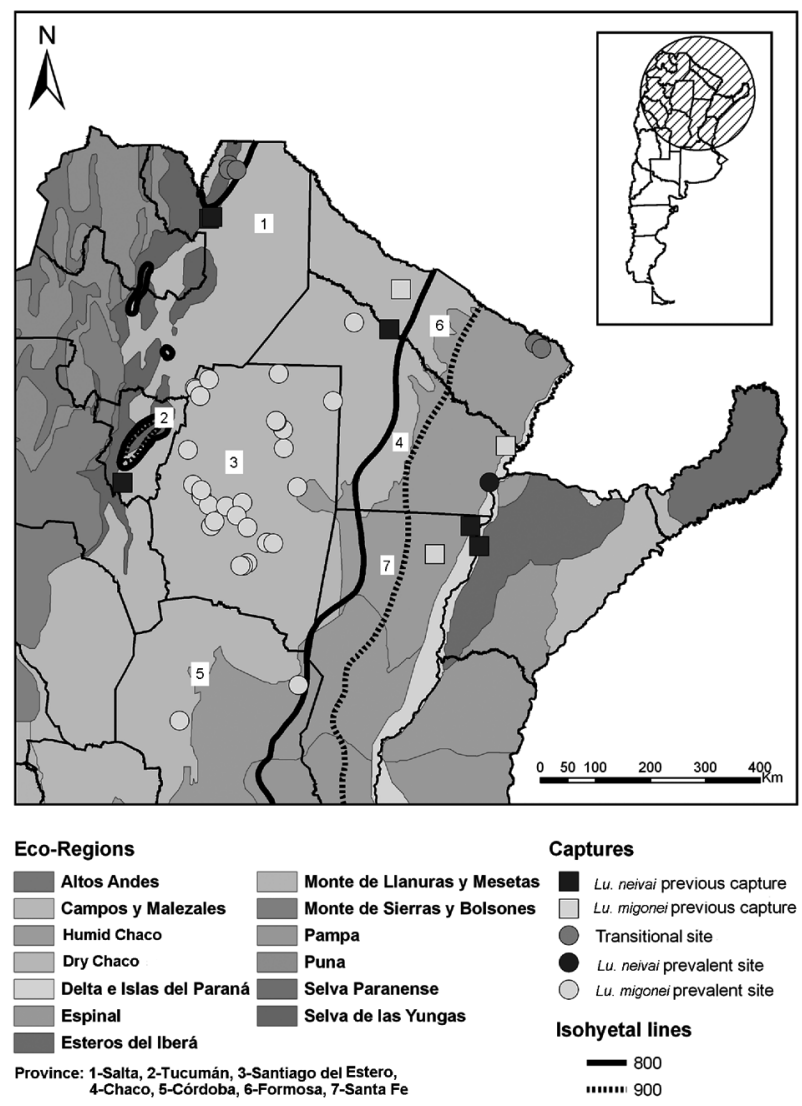

Fig. 1: phlebotomine capture site locations in Chaco region, Argentina, during 2000-2007, along with previous captures cited in the discussion, according to the species prevalence diversity pattern.

captures were performed twice a month from 2001-2003. We computed the geometric mean by month of Lutzomia neivai per night as well as the precipitation and maximal and minimal temperature recorded daily in Resistencia, $8 \mathrm{~km}$ from the capture site (Facultad de Ingenieria, UNNE Resistencia, database), for the entire capture period. Sandflies reported in previous papers from neighboring ecologic regions are presented for comparative purposes, with references and sites reported (Fig. 1).

Statistical analysis - Multiple regression analysis was applied in order to examine the relationship between the geometric means of sandfly abundance and environmental variables (predictors) (InfoStat $2007^{\mathrm{TM}}$ ). The independent variables applied in the analysis included precipitation ( $\mathrm{pp} ; \mathrm{mm}$ ), evapotranspiration (et; $\mathrm{mm}$ piche) and maximum temperature $\left(\mathrm{t}_{\max }{ }^{\circ} \mathrm{C}\right)$. The Pearson simple correlation coefficient was used to determine which variables were included in the multiple lineal regression model, such that minimum temperature $\left(\mathrm{t}_{\text {min }}\right)$ was excluded from the analysis $\left(\mathrm{r}_{\text {tmax-tmin }}=0.95 ; \mathrm{p}\right.$ $<0.001)$. The media and ranges of included variables (11 samples) included precipitation [56.9 (4.6-202.1)], maximum temperature [27.60 (21.31-32.34)] and evapotranspiration [71.42 (15.17-101.42)]. Outliers were detected graphically by residuals of sandfly abundance and data 
TABLE I

Phlebotomine caught with CDC traps by site and species in the Chaco region, Argentina, 2000-2007

\begin{tabular}{|c|c|c|c|c|c|c|c|c|c|c|}
\hline Province & Locality & Month/year & Coordenates $(\mathrm{S}, \mathrm{W})$ & $L n$ & $\mathrm{Lm}$ & $L c$ & $L q$ & Ls & $L p$ & $B r$ \\
\hline Salta & Piquirenda & $10 / 2005$ & $22^{\circ} 23^{\prime} 38^{\prime \prime}, 63^{\circ} 47^{\prime} 45^{\prime \prime}$ & 3 & & & & & & \\
\hline Salta & Tartagal Km 6 & $10 / 2005$ & $22^{\circ} 28^{\prime} 04^{\prime \prime}, 63^{\circ} 47^{\prime} 26^{\prime \prime}$ & 58 & 13 & & & & & 1 \\
\hline Salta & Tartagal Km 18 & $10 / 2005$ & $22^{\circ} 28^{\prime} 14^{\prime \prime}, 63^{\circ} 39^{\prime} 19^{\prime \prime}$ & 27 & 24 & 3 & & & & 1 \\
\hline Tucumán & 7 de Abril & $11 / 2004$ & $26^{\circ} 17^{\prime} 13^{\prime \prime}, 64^{\circ} 30^{\prime} 09^{\prime \prime}$ & 1 & 33 & 3 & & & & \\
\hline St Estero & La Fragua & $11 / 2004$ & $26^{\circ} 03^{\prime} 45^{\prime \prime}, 64^{\circ} 20^{\prime} 45^{\prime \prime}$ & & 25 & 4 & & & & \\
\hline St Estero & El Mojón & $11 / 2004$ & $26^{\circ} 05^{\prime} 15^{\prime},, 64^{\circ} 19^{\prime} 20^{\prime \prime}$ & & 3 & 1 & & & & \\
\hline St Estero & Nueva Esperanza & $11 / 2004$ & $26^{\circ} 11^{\prime} 54^{\prime \prime}, 64^{\circ} 14^{\prime} 53^{\prime \prime}$ & 12 & 78 & 10 & & & & \\
\hline St Estero & Los Quiroga & $11 / 2004$ & $27^{\circ} 39^{\prime} 29^{\prime \prime}, 64^{\circ} 21^{\prime} 14^{\prime \prime}$ & & & 1 & & & & \\
\hline St Estero & Camino de la Costa & $11 / 2004$ & $27^{\circ} 50^{\prime} 51^{\prime \prime}, 64^{\circ} 11^{\prime} 41^{\prime \prime}$ & 1 & 8 & 2 & & & & \\
\hline St Estero & Gral Pinto & $11 / 2004$ & 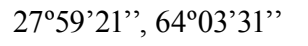 & & & 1 & & & & 1 \\
\hline St Estero & Pozo Hondo & $11 / 2004$ & $27^{\circ} 05^{\prime} 13^{\prime \prime}, 64^{\circ} 27^{\prime} 29^{\prime \prime}$ & & 3 & & & & & \\
\hline St Estero & La Dormida & $11 / 2004$ & $28^{\circ} 19^{\prime} 55^{\prime \prime}, 64^{\circ} 00^{\prime} 31^{\prime \prime}$ & & 2 & 3 & & & & \\
\hline St Estero & Robles & $4 / 2008$ & $27^{\circ} 55^{\prime} 25^{\prime \prime}, 64^{\circ} 05^{\prime} 13^{\prime \prime}$ & & 4 & & & & & \\
\hline St Estero & Brea Pozo & $4 / 2008$ & $28^{\circ} 15^{\prime} 09^{\prime \prime}, 63^{\circ} 56^{\prime} 55^{\prime \prime}$ & & 27 & 4 & & & & \\
\hline St Estero & Tintina & $4 / 2008$ & $27^{\circ} 01^{\prime} 43^{\prime \prime}, 62^{\circ} 42^{\prime} 07^{\prime \prime}$ & & 19 & 2 & & & & \\
\hline St Estero & Donadeu & $4 / 2008$ & $26^{\circ} 43^{\prime} 14^{\prime \prime}, 62^{\circ} 43^{\prime} 28^{\prime \prime}$ & & 28 & $10^{a}$ & & & & \\
\hline St Estero & Campo Gallo & $4 / 2008$ & $26^{\circ} 35^{\prime} 19^{\prime \prime}, 62^{\circ} 50^{\prime} 45^{\prime \prime}$ & & 10 & 2 & & & & \\
\hline St Estero & Huachana & $4 / 2008$ & $26^{\circ} 34^{\prime} 42^{\prime \prime}, 62^{\circ} 51^{\prime} 40^{\prime \prime}$ & & 15 & & & & & \\
\hline St Estero & Monte Quemado & $4 / 2008$ & $25^{\circ} 48^{\prime} 26^{\prime \prime}, 62^{\circ} 49^{\prime} 54^{\prime \prime}$ & & 5 & & & & & \\
\hline St Estero & Taboada & $4 / 2008$ & $28^{\circ} 00^{\prime} 26^{\prime \prime}, 63^{\circ} 44^{\prime} 23^{\prime \prime}$ & & 2 & 1 & & & & \\
\hline St Estero & Suncho Corral & $4 / 2008$ & $27^{\circ} 56^{\prime} 26^{\prime \prime}, 63^{\circ} 26^{\prime} 21^{\prime \prime}$ & & 1555 & 64 & & & & \\
\hline St Estero & Quimili & $4 / 2008$ & $27^{\circ} 39^{\prime} 36^{\prime \prime}, 62^{\circ} 26^{\prime} 09^{\prime \prime}$ & & 10 & 2 & & & & \\
\hline St Estero & Pampa Guanacos & $4 / 2008$ & 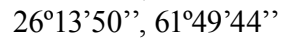 & & 1 & & & & & \\
\hline St Estero & Garza & $4 / 2008$ & $28^{\circ} 09^{\prime} 13^{\prime \prime}, 63^{\circ} 32^{\prime} 29^{\prime \prime}$ & & 22 & 3 & & & & \\
\hline St Estero & Lugones & $4 / 2008$ & $28^{\circ} 20^{\prime} 32^{\prime \prime}, 63^{\circ} 20^{\prime} 06^{\prime \prime}$ & & 1 & 3 & & & & \\
\hline St Estero & Col Dora1 & $4 / 2008$ & $28^{\circ} 35^{\prime} 15^{\prime},, 62^{\circ} 58^{\prime} 15^{\prime \prime}$ & & 1 & 1 & & & & \\
\hline St Estero & Col Dora2 & $4 / 2008$ & $28^{\circ} 35^{\prime} 46^{\prime \prime}, 62^{\circ} 51^{\prime} 00^{\prime \prime}$ & & 3 & & & & & \\
\hline St Estero & Yacu Human & $4 / 2008$ & 285'31'”, 6319'19’' & & 2 & & & & & \\
\hline St Estero & Río Dulce & $4 / 2008$ & $28^{\circ} 58^{\prime} 26^{\prime \prime}, 63^{\circ} 24^{\prime} 06^{\prime \prime}$ & & 4 & & & & & \\
\hline St Estero & Los Telares & $4 / 2008$ & $28^{\circ} 58^{\prime} 47^{\prime \prime}, 63^{\circ} 27^{\prime} 04^{\prime \prime}$ & & 22 & 5 & & & & \\
\hline \multirow[t]{2}{*}{ St Estero } & La Banda (62 sites) & $11 / 2007$ & & & & & & & & \\
\hline & & $4 / 2008$ & $27^{\circ} 44^{\prime}-45^{\prime}, 64^{\circ} 12^{\prime}-15^{\prime}$ & 2 & 115 & 14 & & & & \\
\hline \multirow[t]{2}{*}{ Chaco } & Nueva Pompeya & $10 / 2006$ & & & & & & & & \\
\hline & & 9/2007 & $24^{\circ} 55^{\prime} 57^{\prime \prime}, 61^{\circ} 30^{\prime} 01^{\prime \prime}$ & 2 & 1333 & 157 & 20 & & 46 & \\
\hline \multirow[t]{2}{*}{ Chaco } & Monte alto & 9/2001 & & & & & & & & \\
\hline & & $10 / 2003$ & $27^{\circ} 26^{\prime} 42^{\prime \prime}, 58^{\circ} 54^{\prime} 51^{\prime \prime}$ & 3365 & 40 & 15 & & 19 & & 5 \\
\hline \multirow[t]{2}{*}{ Córdoba } & Altos de Chipión & $11 / 2004$ & & & & & & & & \\
\hline & & $5 / 2005$ & $30^{\circ} 54^{\prime} 19^{\prime \prime}, 62^{\circ} 18^{\prime} 11^{\prime \prime}$ & & 23 & & & & & \\
\hline Formosa & Laguna Blanca & $10 / 2007$ & $25^{\circ} 08^{\prime} 26^{\prime \prime}, 58^{\circ} 14^{\prime} 26^{\prime \prime}$ & 29 & 1 & & & & & \\
\hline Formosa & Lagun Naineck & $10 / 2007$ & $25^{\circ} 12^{\prime} 53^{\prime \prime}, 58^{\circ} 07^{\prime} 12^{\prime \prime}$ & 8 & & & & & & 1 \\
\hline
\end{tabular}

a: two Lutzomyia cortelezzii males and two Lutzomyia sallesi males (the males in the other sites were all L. cortelezzii); Br: Brumptomyia spp.; Lc: Lutzomyia cortelezzii complex (Lu. cortelezzii-Lu. sallesi); Lm: Lutzomyia migonei; Ln: Lutzomyia neivai; Lp: Lutzomyia peresi; Lq: Lutzomyia quinquefer; Ls: Lutzomyia shannoni.

collected in November were considerer outliers. The fulfillment of independence, homoscedasticity and normality in the multiple linear regression model was tested. The best combination of predictors was considered to be the one that had all terms in the equation below a significant level $(\mathrm{p}<0.05)$ and the highest determination coefficient $\left(\mathrm{R}^{2}\right)$. No validation was performed for the selected model.

Human ACL cases - The average and standard deviation of the cases reported by the Central Laboratory of Chaco province and the Direction of Epidemiology of Santiago del Estero province were computed and classi- fied as either the $\mathrm{DC}$ or $\mathrm{HC}$, according to the reporting department (intra-province political districts). Cases reported from the Formosa province were not included, as each department has a dry and a humid area. The population denominator was taken as the middle period point according to the 2001 census (INDEC 2001).

\section{RESULTS}

The phlebotomine caught by species in the Chaco region and the captures sites are shown in Table I and Fig 1. In the Monte Alto capture site located in the $\mathrm{HC}$ near the Parana river, Lu. neivai is abundant and in greater 
numbers than the remaining species. Lutzomyia migonei is prevalent in many sites of the DC in the provinces of Santiago del Estero, Tucumán and Chaco. In Córdoba, however, Lu. migonei is the sole species found and the first phlebotomine recorded for the province. The fly was captured in Icho Cruz using a Malaise trap. In Los Quiroga and General Pinto, the only species that was captured was Lutzomyia cortelezzii-sallesi (females indistinguishable) and Brumptomyia spp. (females indistinguishable), although both are zoophilic and lack a proven association with ACL transmission. The collections made in the highly modified environments of the Formosa region (at an industrial chicken farm in Laguna Blanca), and the Yungas-Chaco transitional ecotones of Salta showed few sandflies, with $\mathrm{Lu}$. neivai prevalent, or almost equal in abundance to $L u$. migonei in the more typical Chacoan landscape (Tartagal Km 18).

Captures at Suncho Corral were performed simultaneously in a pigpen and an adjoining stable, 323 sandflies were collected in the former and 1,296 close to the horses. Lu. migonei was significantly more abundant in the stable than in the pigsty $(1,259 / 296)$, but neither $L u$. cortelezzii abundance (27/37) nor the sex ratio females/ males (Lu. migonei 0.6-0.7, Lu. cortelezzii 2.8-2.0) in both sites were significantly different.

$L u$. neivai isolated in the HC showed a bimodal annual pattern with an activity season that spikes from March-April (autumn), with its highest peak in November (spring) (Fig. 2). During the drier and colder winter, only a few flies were captured. The $L u$. neivai adult populations abruptly recovered during the rainy season and subsequently decreased during the months of lower precipitation or higher temperatures, until the fall when the population progressively increased.

The best combination of climatic predictors of sandfly abundance includes precipitation as a polynomial of the second degree: $\ln$ sandflies $\left(\mathrm{t}_{\max }, \mathrm{et}, \mathrm{pp}\right)=-118.73+$ $8.84 \mathrm{t}_{\max }-0.55$ et $-1.48 \mathrm{pp}+0.01 \mathrm{pp}^{2}$. The regression coefficients with the corresponding $95 \%$ confidence intervals (CI 95\%), $p$-values and $\mathrm{R}^{2}$ of the best model obtained are shown in Table II.

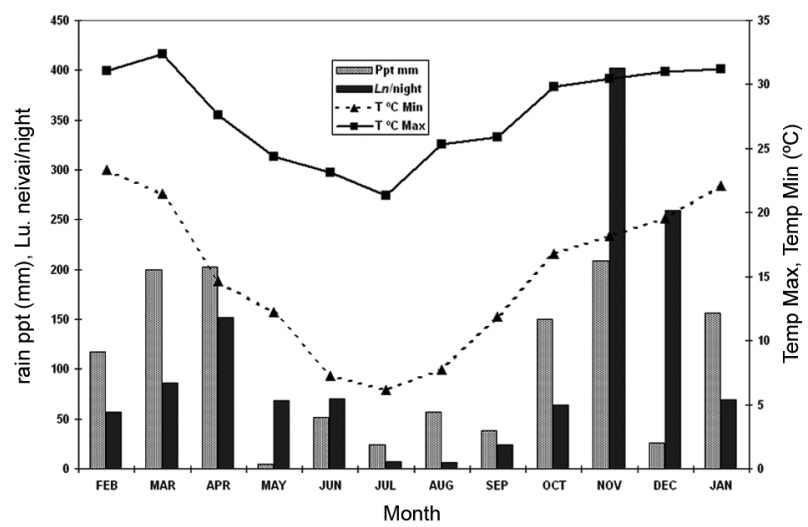

Fig. 2: Lutzomyia neivai/night ( $L n /$ night) abundance in Monte Alto, precipitation (ppt mm) and maximal $\left(\mathrm{T}^{\circ} \mathrm{C}\right.$ Max) and minimal $\left(\mathrm{T}^{\circ} \mathrm{C}\right.$ Min) temperature in Resistencia, geometric mean averaged by month, Chaco, Argentina, 2001-2.
TABLE II

Regression coefficients with the corresponding 95\% confidence intervals (CI), p-values and $\mathrm{R}^{2}$ of the best model obtained

\begin{tabular}{lrcl}
\hline Variable & Coefficients & CI 95\% & p-value \\
\hline Maximum temperature & 8.84 & $5.45 / 12.24$ & 0.00007 \\
Evapotranspiration & -0.55 & $0.98 /-0.13$ & 0.0179 \\
Precipitation $^{2}$ & -1.48 & $-2.21 /-0.74$ & 0.0027 \\
Precipitation $^{2}$ & 0.01 & $0.0041 / 0.01$ & 0.0014 \\
Constant $^{2}$ & -118.73 & $-204.08 /-33.37$ & 0.0144 \\
$\mathrm{R}^{2}$ & 0.92 & & \\
\hline
\end{tabular}

The cumulative 244 ACL cases reported in the province of Chaco from 1994-2005 were produced by 23 of its 25 departments. This includes the departments with the highest rates in each region; the cases of ACL reported in the humid region were $10.7( \pm 4.8)$ cases $/ 10,000$ inhabitants (Libertad, Bermejo, 1st Mayo, Libertador General San Martín), and the cases reported in the dry region were $5.2( \pm 1.5)$ cases $/ 10,000$ inhabitants (9th Julio, Almirante Brown, Gral. Güemes, Independencia).

In Santiago del Estero there were 111 cumulative cases of Leishmaniasis between 1996-2005, although 28 were secondary muco-cutaneous cases and seven were cutaneous with more than a year of evolution according to documentation. The remaining 77 ACL cases were reported from 14 of 27 departments. The departments along the Northern border of Salta and Chaco were among the four departments with the highest rates (Pellegini, 20.5/10,000 inhabitants, and Copos, 3.7/10,000). However, in both departments, the majority of the cases were in the hyperendemic area of Salta or Catamarca during the infection period. Furthermore, the Southern contiguous departments reported few cases (Alberdi, 1.2/10,000, and Jimenez, 0 cases). However, San Martín and Loreto, South of the capital in the Rio Dulce basin, had 6.6 and 2.3 cases $/ 10,000$, respectively. These cases included at least five familiar clusters with two to six individuals.

\section{DISCUSSION}

The results presented here support the hypothesis that in the Argentinean Chaco two main diversity patterns of phlebotomine captures are observed: (1) $\mathrm{Lu}$. migonei as the prevalent species with or without scarce Lu. neivai in the DC and (2) Lu. neivai as a highly abundant and prevalent species with scarce $L u$. migonei in the HC (Salomón et al. 2005). Intermediate results with $\mathrm{Lu}$. neivai showing increasing prevalence were observed in modified humid periurban sites (Laguna Blanca industrial chicken farm, Laguna Naineck pigsty), or proximal to the Yungas subtropical foothills (gradient from Piquirenda to Tartagal km 6 to Tartagal $\mathrm{km} 18$ had almost an equal abundance of both species). This relative abundance distribution was previously observed in the Formosa province where the $\mathrm{Lu}$. neivai/Lu. migonei ratio in the Bermejo river subtropical gallery forest was $18.6(n=3,292)$, in contrast to a ratio of $0.1(n=41)$ in the Chacoan dry landscape near the Pilcomayo river (a similar capture effort with traps was used there). In 
the Santa Fe province on the Parana river shore, this ratio was $855(\mathrm{n}=856)$, while it was $1.5(\mathrm{n}=5)$ in the former Chaco woodlands, which have been deforested since the 1950s (Salomon 2006a, b).

Despite the different capture efforts, the traps in $L u$. migonei prevalent sites generally had fewer individuals per night than captures in the $L u$. neivai prevalent sites reported here. A high abundance of Lu. neivai, prevalent over $L u$. migonei, was also reported in the captures related to epidemic ACL outbreaks in modified environments from the subtropical humid regions on both sides of the Argentinean DC. In the Western Yungas foothills, the observed Lu. neivai/Lu. migonei ratio was 14.1 $(\mathrm{n}=953)$ in Alberdi, Tucumán, and $96.2(\mathrm{n}=50,457)$ in Pichanal/Embarcación, Salta. In the eastern Paranaense region, in Bella Vista, Corrientes, the ratio was 120.4 $(\mathrm{n}=3,279)$ (Salomón et al. 2004, 2006d, e). Furthermore, the sandfly captures made in Argentina prior to 1950 reported $L u$. migonei and $L u$. cortelezzii in the Santiago del Estero and Formosa provinces, but Lu. neivai (as Flebotomus intermedius) was only reported in sites of the humid region of the Chaco province (Castro 1959). Lu. cortelezzii historical records should be taken cautiously as the species of the cortelezzii series are very similar or sometimes indistinguishable ( $L u$. cortelezzi-Lu. sallesi females) (Galati et al. 1989, Young \& Duncan 1994, Galati 2003), and many times sympatric as Lu. cortelezzii and $L u$. sallessi in the captures made at Donadeu, Santiago del Estero reported here. However, these findings represent the first report of Phlebotominae sandflies in the Cordoba province and the southernmost record of Lu. migonei in the Central region of Argentina.

Lu. migonei and Lutzomyia intermedia, which are closely related to $L u$. neivai, were incriminated as peridomestic vectors of ACL in foci due to Leishmania braziliensis (Azevedo et al. 1990, Pita-Pereira et al. 2005). This parasite was isolated from human ACL cases during ACL outbreaks in Argentina, from ACL cases in Santiago del Estero, and from $\mathrm{Lu}$. neivai caught in Tucumán (Cuba-Cuba et al. 1996, Segura et al. 2000, Cordoba-Lanus et al. 2005, 2006). Lu. neivai is associated with epidemic outbreaks in highly modified environments, while, Lu. migonei is a relatively zoophilic vector, comparatively, which is highly attracted to horses in Argentina and may be involved in the link between the zoonotic and the anthropozoonotic transmission cycles (Chaves \& Añez 2004). Many species of vertebrates usually cited as blood sources of phlebotomine are characteristic of the Chaco even edentate, the main source for Brumptomyia spp. (Zuleta \& Bolcovic 1994).

The recent epidemics reported in the Argentinean Chaco region were located in the humid region or were found to be related to the gallery forests of the rivers from the Yungas and Paranaenese basins, where $L u$. neivai is the prevalent species. ACL outbreaks were reported in: (1) the General Vedia and Cancha Larga Chaco (Miranda et al. 1999, Salomón et al. 2001); (2) in San Martín, Loreto, Atamisqui and Silipica, Santiago del Estero, with peridomestic transmission enhanced by closeness to the rivers (Yadón et al. 2001, 2003); and (3) in Laishi (Basualdo unpublished observations) and Lo- mitas, Formosa (Salomón et al. 2006b) on the Bermejo river gallery forest that extends the Yungas landscape inside the DC region (Sennhauser 1991). The annual pattern of Lu. neivai in the $\mathrm{HC}$ was similar to that which was described for the Yungas region (Salomón et al. 2004): it was bimodal, with the highest peak in spring and another peak in the fall, depending on the precipitation and temperature. The precipitation-temperature dependence of $L u$. neivai abundance was also observed in the multiple linear regression model. Interestingly, if the sandfly captures in November are excluded, the obtained $\mathrm{R}^{2}$ is as high as 0.92 , suggesting that the climatic variables explain the annual dynamics but not the highest peak. However, it should be noted that the model is limited due to the scarce number of samples and requires further validation. The Lu. neivai peak could be related to an autocorrelation component of the sandfly population, or to unsynchronized climatic data (precipitation lag) (Salomón et al. 2004).

In the $\mathrm{DC}$ area, where $\mathrm{Lu}$. migonei is prevalent, there are annual isolated cases or limited, focused, familiar or "hot spot"-related case clusters, as is typical in zoonotic cycle scenarios. However, there are reports of Leishmania guyanensis and Leishmania amazonensis infections in the area besides Le. braziliensis (Frank et al. 2003, Marco et al. 2005, 2006). Parasite characterization in both Chacoan vectors and human cases is currently an ongoing project.

Therefore, the case reporting distribution of sandfly diversity and dynamics (with the antecedents discussed above) supports the hypothesis of two different ACL transmission patterns: (1) the DC, where Lu. migonei was the prevalent species, had isolated ACL cases and a zoonotic cycle, and (2) the HC, where Lu. neivai was the prevalent species and in high abundance, had an increase in ACL incidence and outbreaks, and an anthropozoonotic cycle. Furthermore, during the pre-epidemic period prior to the $1950 \mathrm{~s}, \mathrm{Lu}$. neivai was not recorded in the hyperendemic/epidemic area of the Salta province (Castro 1959), while it is highly abundant today (Salomón et al. 2004).

In conclusion, the ACL vector sandfly fauna of the DC region was typically represented by $L u$. migonei with $L u$. neivai in lesser abundance or absent. The ACL transmission in this area was consistent with zoonotic cycles, scattered cases, or accidental intrusion within sandfly-infected "hot spot" environments. However, the $\mathrm{HC}$ and the gallery forest were related to subtropical humid basins and showed a pattern of Lu. neivai prevalence with fewer $L u$. migonei, similar to the pattern observed in the emergent epidemic scenarios of the subtropical Yungas foothills and the Paranaense woods in peridomestic environments. The $L u$. neivai annual dynamics in the $\mathrm{HC}$ region, which were similar to those of the Yungas-Paranense epidemic region, were dependent on rain and temperature.

There are important public health implications for the relationships between increased prevalence and abundance of $L u$. neivai, increased ACL incidence and epidemic risk, as well as factors including landscape modification, connections with ACL zoonotic or anthro- 
pozoonotic foci and rising humidity. The climate trends observed in the region show a steady increase in rain precipitation that will extend the current agriculture-exploitable area and is enhanced by ENSO activity (Villalba et al. 1998, Minetti et al. 2003, Haylock et al. 2006). Consequently, an increase of ACL emergence can be expected in the Chaco region. The sandfly pattern changes from $\mathrm{Lu}$. migonei-prevalent populations to $\mathrm{Lu}$. neivai-prevalent/abundant populations can also be used as an indicator for forecasting epidemic risk at sentinel capture sites.

\section{ACKNOWLEDGEMENTS}

To the authors' respective institutions, for their administrative and technical support, the Facultad de Ingeniería, Departamento de Hidráulica, UNNE, for providing the weather data, and Federico Vianconi (CNCV, Oran), Ricardo Vélez and Julio Ovejero (MSDH Santiago del Estero), Carlos Pino (MDH Formosa), Eliana Tapia, Enrique Szelag and Juana Willener (UNNE, Chaco), for their generous help with sandfly collections.

\section{REFERENCES}

Adamoli J, Sennhauser EB, Acero JM, Rescia AJ 1990. Stress and disturbance: vegetation dynamics in the dry Chaco Region of Argentina. J Biogeography 17: 491-500.

Andrade Filho JD, Galati EA, Falcão AL 2003. Redescription of Nyssomyia intermedia (Lutz \& Neiva 1912) and Nyssomyia neivai (Pinto 1926) (Diptera: Psychodidae). Mem Inst Oswaldo Cruz 98: 1059-1065.

Azevedo ACR, Rangel EF, Queiroz RG 1990. Lutzomyia migonei (França 1920) naturally infected with peripylarian flagellates in Baturité, a focus of cutaneous leishmaniasis in Ceará State, Brazil. Mem Inst Oswaldo Cruz 85: 479.

Bucher EH, Huszar PC 1999. Sustainable management of the Gran Chaco of South America: Ecological promise and economic constrains. J Env Man 57: 99-108.

Cabrera AL 1976. Regiones fitogeográficas Argentinas. In AL Cabrera, Enciclopedia Argentina de Agricultura y Jardineria, Tomo II, Fascículo I. Editorial ACME SACI, Buenos Aires, p. 1-85.

Campbell-Lendrum D, Dujardin JP, Martínez E, Feliciangeli MD, Pérez JE, Silans LN, Desjeux P 2001. Domestic and peridomestic transmission of American cutaneous leishmaniasis: changing epidemiological patterns present new control opportunities. Mem Inst Oswaldo Cruz 96: 159-162.

Castro M 1959. Diptera: Psychodidae - Flebotominae. In JRF Bejarano, E del Ponte, RN Orfila, Primeras Jornadas Entomoepidemiológicas Argentinas, La Prensa Médica, Buenos Aires, p. 545-546.

Chaves LF, Añez N 2004. Species co-occurrence and feeding behavior in sand fly transmission of American cutaneous leishmaniasis in western Venezuela. Acta Tropica 92: 219-224.

Córdoba-Lanús E, Lizarralde de Grosso M, Piñero JE, Valladares B, Salomón OD 2006. Natural infection of Lutzomyia neivai with Leishmania spp. in northwestern argentina. Acta Tropica 98: 1-5.

Córdoba-Lanús E, Piñero JE, González AC, Valladares B, de Grosso ML, Salomón OD 2005. Detection of Leishmania braziliensis in human paraffin-embedded tissues from Tucuman, Argentina by polymerase chain reaction. Mem Inst Oswaldo Cruz 100: 187-192.

Cuba-Cuba CA, Torno CO, Ledesma O, Visciarelli E, García S, Prat MI, Costamagna R, Barbieri L, Evans DA 1996. Human mucocutaneous leishmaniasis caused by Leishmania (Viannia) brasiliensis in Santiago del Estero, Argentina: identification of parasites by monoclonal antibodies and isoenzymes. Rev Inst Med Trop São Paulo 38: 413-421.

Desjeux P 2001. The increase in risk factors for leishmaniasis worldwide. Trans R Soc Trop Med Hyg 95: 239-243.

Frank FM, Fernandez MM, Taranto NJ, Cajal SP, Margni RA, Castro E, Thomas-Soccol V, Malchiodi EL 2003. Characterization of human infection by Leishmania spp. in the Northwest of Argentina: immune response, double infection with Trypanosoma cruzi and species of Leishmania involved. Parasitology 126: 31-39.

Galati EAB 2003. Morfologia, terminologia de adultos e identificação dos táxons da América. In EF Rangel, R Lainson, Flebotomíneos do Brasil, Editora Fiocruz, Rio de Janeiro, p. 53-176.

Galati EAB, Nunes VLB, Oshiro ET, Rego FA 1989. Descrição de uma nova espécie de Phlebotominae Lutzomyia corumbaensis, sp. n. (Diptera, Psychodidae) do complexo Lutzomyia cortelezzii. Rev Bras Entomol 33: 465-475.

González G, Arce Queirolo A 1955. Leishmaniosis. II. Leishmaniosis cutáneo-mucosa y guerra en el Bosque. Rev Méd Paraguay 1: 69-74.

González G, Oliveira y Silva M 1939. La leishmaniosis forestal americana en la guerra del Chaco. Novena Reunión Sociedad Argentina de Patología Regional, tomo 2, p. 959-974.

Haylock MR, Peterson TC, Alves LM, Ambrizzi T, Anunciação MT, Baez J, Barros VR, Berlato MA, Bidegain M, Coronel G, Corradi V, García VJ, Grimm AM, Karoly D, Marengo JA, Marino MB, Moncunill DF, Nechet D, Quintana J, Rebello E, Rusticucci M, Santos JL, Trebejo I, Vincent LA 2006. Trends in total and extreme South Amerian Rainfall in 1960-2000 and Limks with Sea Surface Temperature. J Climate 19: 1490-1512.

INDEC-Instituto Nacional de Estadisticas y Censos 2001. Censo Nacional 2001. Available at: http://www.indec.mecon.ar/webcenso/index.asp.

Marco JD, Barroso PA, Calvopina M, Kumazawa H, Furuya M, Korenaga M, Cajal SP, Rea MM, Borda CE, Basombrío MA, Taranto MM, Hashiguchi Y 2005. Species assignation of Leishmania from human and canine american tegumentary leishmaniasis cases by multilocus enzyme electrophoresis in North Argentina. Am J Trop Med Hyg 72: 606-611.

Marco JD, Uezato H, Mimori T, Baroso PA, Korenaga M, Nonaka S, Basombrio MA, Taranto NJ, Hashiguchi Y 2006. Are Cytochrome $\mathrm{B}$ gene sequencing and polymorphism-specific polymerase chain reaction as reliable as multilocus enzyme electrophoresis for identififying Leishmania spp. from Argentina? Am J Trop Med Hyg 75: 256-260.

Minetti JL, Vargas WM 1997. Trends and Jumps in the annual precipitation in South America, south of the $15^{\circ}$ S. Atmosfera 11: 205-221.

Minetti JL, Vargas WM, Poblete AG, Acuna LR, Casagrande G 2003. Non-linear trends and low frequency oscillations in annual precipitation over Argentina and Chile, 1931-1999. Atmosfera 16: 119-135.

Miranda O, Balbachán S, Galván M, Moro S, Gorodner OZ, Salazar J, Merino SO 1999. Brote de Leishmaniosis en Cancha Larga, Chaco, Argentina. Rev Cubana Med Trop 51: 69-71.

Morello J, Adamoli J 1968. Las grandes unidades de vegetación y ambiente del Chaco Argentino II. INTA, Serie Fitogeográfica 10: $1-126$.

Mott KE, Desjeux P, Moncayo A, Ranque P, de Raadt P 1990. Parasitic diseases and urban development. Bull World Health Organ 68: 691-698. 
Pita-Pereira D, Alves CR, Souza MB, Brazil RP, Bertho AL, de Figueiredo Barbosa A, Britto CC 2005. Identification of naturally infected Lutzomyia intermedia and Lutzomyia migonei with Leishmania (Viannia) braziliensis in Rio de Janeiro (Brazil) revealed by a PCR multiplex non-isotopic hybridisation assay. Trans R Soc Trop Med Hyg 99: 905-913.

Prohaska F 1959. El polo de Calor de América del Sur. INTA, IDIA: 141: $27-30$.

Salomón OD, Bogado de Pascual M, Molinari ML, Verri V 2001. Study of a cutaneous leishmaniasis outbreak in General Vedia, Province of Chaco. Rev Inst Med Trop São Paulo 43: 99-104.

Salomón OD, Mocarbel NJ, Pedroni E, Colombo J, Sandillú M 2006a. Phlebotominae: vectores de leishmaniasis en las provincias de Santa Fe y Entre Ríos, Argentina. Medicina (Buenos Aires) 66: 220-224.

Salomón OD, Orellano PW, Lamfri M, Scavuzzo M, Drí L, Farace MI, Ozuna Quintana D 2006b. Phlebotominae spatial distribution associated with a focus of tegumentary leishmaniasis in Las Lomitas, Formosa, Argentina, 2002. Mem Inst Oswaldo Cruz 101: 295-299.

Salomón OD, Orellano PW, Quintana MG, Pérez S, Sosa Estani S, Acardi S, Lamfri M 2006c. Transmisión de la leishmaniasis tegumentaria en Argentina. Medicina (Buenos Aires) 66: 211-219.

Salomón OD, Quintana MG, Flores I, Andina AM, Molina S, Montivero L, Rosales I 2006d. Phlebotominae sand flies associated with a tegumentary leishmaniosis outbreak, Tucuman Province, Argentina. Rev Soc Bras Med Trop 39: 341-346.

Salomón OD, Quintana MG, Orellano P, Stein M, Rosa JR, Acardi S, Lamfri M, Scavuzzo M 2005. Phlebotominae associated with leishmaniasis foci in Argentina, 1990-2004. Arch Inst Pasteur Tunis 82: 24-25.

Salomón OD, Sosa-Estani S, Ramos K, Orellano PW, Sanguesa G, Fernández G, Sinagra A, Rapasciolli G 2006e. Tegumentary leishmaniasis outbreak in Bella Vista City, Corrientes, Argentina during 2003. Mem Inst Oswaldo Cruz 101: 767-774.

Salomón OD, Wilson ML, Musntermann LE, Travi BL 2004. Spatial and temporal patterns of phlebotomine sand flies (Diptera: Psychodidae) in a cutaneous leishmaniasis focus in northern Argentina. J Med Entomol 41: 33-39.
Segura EL, Juan N, Piquín AL, Cuba-Cuba CA, Abramo Orrego L, McMahon-Pratt D, Montamat EE, Momen H, Grimaldi Jr G 2000. Molecular and biologic characterization of Leishmania parasites implicated in an epidemic outbreak in northwestern Argentina. Parasitol Res 86: 504-508.

Sennhauser EB 1991. The concept of stability in conection with gallery forest of the Chaco region. Vegetatio 94: 1-13.

Shaw J 2007. The leishmaniases-survival and expansion in a changing world. Mem Inst Oswaldo Cruz 102: 541-547.

Sudia WD, Chamberlain RW 1962. Battery operated light trap, an improved model. Mosquito News 22: 126-129.

Trucco Aleman CE 2007. Livestock and native fauna: changes affecting predation and secondary dispersal of seeds of woody plant in the semiarid Chaco woodland, Copo National Partk and surroundings, Argentina. In CE Trucco Aleman, Rufford Small Grant for Nature Conservation. Final Report (2006-2007), p. 1-27. Available at : http://www.ruffordsmallgrants.org/files/RSG_Final\%20 Report_Trucco\%20Alem\%C3\%A1n.doc.

UNNE 1987. El Medio Natural. In UNNE, Atlas geográfico de la provincia del Chaco, Tomo I, $\mathrm{n}^{\circ}$ 5, Resistencia, p. 1-19.

Villalba R, Grau HR, Boninsegna JA, Jacoby GC, Ripalta A 1998. Treering evidence for long-term rainfall changes in South America. Int J Climatol 18: 1463-1478.

Yadón ZE, Quigley MA, Davies CR, Rodrigues LC, Segura EL 2001 Assessment of Leishmaniais Notification System in Santiago del Estero, Argentina, 1990-1993. Am J Trop Med Hyg 65: 27-30.

Yadón ZE, Rodrigues LC, Davies CR, Quigley MA 2003. Indoor and peridomestic transmission of American Cutaneous Leishmaniasis in Northwestern Argentina: a retrosopective case-control study. Am J Trop Med Hyg 68: 519-526.

Young DG, Duncan MA 1994. Guide to the identification and geographic distribution of Lutzomyia sand flies in Mexico, the West Indies, Central and South America (Diptera: Psychodidae). Mem Am Entomol Inst 54: 1-881.

Zuleta G, Bolkovic ML 1994. Conservation ecology of Armadillos in the Chaco region of Argentina. Edentata 1: 16-17. 